JBE Vol. 5 , No. 2 , 2020, pp: 27 - 36

\title{
KAJIAN EMPIRIS TERHADAP STRUKTUR MODAL PERUSAHAAN DI INDUSTRI MANUFAKTUR.
}

\author{
Dwi Astutik ${ }^{1)}$, Hesti Ristanto ${ }^{2)}$, Hani Krisnawati ${ }^{3)}$ \\ Institut Teknologi Bisnis Semarang, Indonesia
}

\section{Info Artikel}

Sejarah Artikel:

Diterima : 10 Juli 2020

Disetujui : 13 Juli 2020

Dipublikasikan : 13 Juli 2020

\section{Keywords:}

Profitabilitas; likuiditas; struktur modal.

\begin{abstract}
Abstrak
Tujuan dari penelitian ini adalah melakukan pengujiann empiris mengenai pengaruh antara profitabilitas dan likuiditas terhadap struktur modal. Objek penelitian dilakukan pada perusahaan-perusahaan yang telah go public dan termasuk dalam industri Manufaktur. Pengambilan data menggunakan penggabungan metode by firm dan by years, dan diperoleh 589 data.

Hasil pengujian membuktikan bahwa secara parsial,profitabilitas dan likuiditas berpengaruh negatip dan signifikan terhadap struktur modal. Saran yang dapat direkomendasikan bagi para akademisi dapat dijadikan acuan sebagai pengembangan pengujian terhadap pecking order theory. Bagi para pihak yang ada di jajaran manajerial perusahaan, menjadi rambu-rambu dalam pengambilan keputusan dalam menyusun struktur modalnya. Bagi calon investor dan investor, hasil penelitian ini dapat dijadikan sebagai salah satu bahan pertimbangan dari aspek fundamental dalam pengambilan keputusan investasi.
\end{abstract}

\begin{abstract}
Abstrcak
The purpose of this study is to conduct an empirical test of the effect between profitability and liquidity on capital structure. The object of research is conducted on companies that have gone public and are included in the Manufacturing industry. Retrieval of data using a combination of methods by firm and by years, and obtained 589 data.

The test results prove that partially, profitability and liquidity have a negative and significant effect on capital structure. Suggestions that can be recommended for academics can be used as a reference as the development of testing of pecking order theory. For the parties in the managerial level of the company, they become the guidelines in making decisions in preparing their capital structure. For potential investors and investors, the results of this study can be used as a material consideration from the fundamental aspects of investment decision making.

\footnotetext{
Alamat : Jl Jendral Sudirman no 346 Institut Teknologi Bisnis Semarang

E-mail: hestiristanto@gmail.com
} 


\section{PENDAHULUAN}

Negara Republik Indonesia pada era saat ini mempunyai pertumbuhan ekonomi yang baik, diantara negaranegara lainnya. Dampak positipnya bahwa kondisi ini menjadi negara yang dituju oleh para investor baik dalam negeri maupun luar negeri dalam melakukan investasi. Perkembangan perkembangan investasi yang berarti ini dimulai sejak tahun 2011, hingga trend positip terus berlanjut sampai dengan tahun 2017 (okezone.com. Download 20 November 2017). Perkembangan investasi di Indonesia terus membaik pada kuartal II/2017 (April-Juni). Menurut Badan Koordinasi Penanaman Modal (BKPM), realisasi investasi pada periode ini menyentuh Rp. 170,9 triliun. Angka ini menujukkan kenaikan $12.7 \%$ dari periode yang sama pada tahun 2016. Saat itu, realisasi investasi baik dari dalam maupun luar negeri mencapai Rp151,6 triliun. Dirilis oleh (okezone.com. Download 20 November 2017).

Ragam instrumen investasi yang ada di masyarakat belakangan ini salah satunya investasi dalam bentuk surat berharga di pasar modal. Salah satu jenis surat berharga sebagai media investasi adalah berupa saham. Saham perusahaan go public sebagai komoditi investasi tergolong berisiko tinggi. Hal ini dikarenakan sifatnya yang peka terhadap perubahan-perubahan yang terjadi, baik oleh pengaruh yang bersumber dari luar atau dalam negeri. Kinerja setiap industri berbeda antara industri satu dengan yang lain, baik dalam hal kemampuannya menciptakan return, maupun daya tahan masing-masing industri dalam menghadapi gejolak ekonomi domestik ataupun global. Dimulainya kerjasama ekonomi antar negara-negara anggota ASEAN yaitu sejak disahkannya Deklarasi Bangkok tahun 1967 membuat para pemilik modal untuk bekerja keras.
Laporan tersebut juga didukung research yang dilakukan oleh Ibrahim (2015) mengungkapkan bahwa pada tinjauan teoritis menjelaskan, dengan adanya MEA, sebagai bentuk integrasi ekonomi memiliki setidaknya dua implikasi yaitu manfaat dan kerugian. Dilihat dari sudut pandang manfaat, adanya MEA dapat memberi akses pasar yang lebih luas serta menurunkan tarif perdagangan. Disisi lain, ada dampak negatifnya yaitu suatu negara berpotensi menjadi pasar, bagi perusahaan yang memiliki daya saing rendah. Lebih lanjut dinyatakan bahwa integrasi ekonomi pada akhirnya akan menciptakan skema persaingan antar negara yang tergabung dalam integrasi ekonomi. Persaingan ini pada akhirnya menuntut setiap negara untuk meningkatkan daya saingnya yang disebut sebagai pro-competitive effect (http://etd.repository.ugm).

Penelitian ini mencoba mengkaji pada industri Manufaktur yang tercatat di Bursa Efek Indonesia (BEI), dari perspektif faktor-faktor yang mempengaruhi struktur modal. Pemilihan industri manufaktur ini didasarkan pada Laporan Kementerian Keuangan (2014:37) yang diunduh dari (https://www.kemenkeu.go.id).

Dinyatakan bahwa daya saing produkproduk manufaktur atau komoditas ekspor Indonesia, ternyata tidak semua memiliki daya saing tinggi di pasar internasional.

Dinyatakan pula oleh bank HSBC, bahwa industri Manufaktur domestik memprihatinkan. Indikasinya dapat dilihat dari purchasing managers indeks (PMI) yang turun 2 point. Berdasarkan hal tersebut, pada saat ini Indonesia mengalami permasalahan terkait rendahnya kinerja dan daya saing industri manufaktur yang juga tergabung ke dalam integrasi ekonomi ASEAN 2015, dengan konsep pro competitive effect (http://etd.repository.ugm). 
Kinerja perusahaan dapat dilihat dari bagaimana pasar menilai atas perusahaan tersebut dilihat dari struktur modal dan nilai peruahaan. Berdasarkan studi empiris yang dilakukan oleh Purwohandoko (2017) yang melakukan penelitian mengenai pengaruh profitabilitas terhadap struktur modal. Hasil penelitian membuktikan bahwa profitabilitas berpengaruh negatip dan signifikan terhadap struktur modal perusahaan-perusahaan yang tercatat pada industri Agruculture. Disisi lain, penelitian Putu (2014) membuktikan sebaliknya, dimana profitabilitas berpengaruh positip dan signifikan terhadap struktur modal perusahaan di industri Manufaktur.

Salavati dan Rasaiian et al (2007) dalam dalam Alfi et al (2016) tidak menemukan pengaruh yang signifikan $(95 \%)$ antara variabel likuiditas dan profitabilitas terhadap struktur modal. Penelitian Handoko (2016) membuktikan bahwa likuditas berpengaruh positip tidak signifikan terhadap struktur modal.

Fenomena tersebut menarik bagi para akademisi dan praktisi untuk melakukan penelitian. Maka penelitian ini dilakukan untuk menguji kembali pengaruh faktor fundamental terhadap struktur modal perusahaan-perushaan khususnya yang termasuk ke dalam industri Manufaktur.

\section{METODE}

Penelitian ini dilakukan dengan menggunakan pendekatan kuantitatif, dengan jenis data, sekunder yang bersumber dari dokumen indonesian capital market directory, dengan teknik pengumpulan data documentary. Penelitian diukur dengan menggunakan variabel profitabilitas (return on assets), likuiditas (current ratio), dan struktur modal (debt to equity ratio). Teknik analisis menggunakan least square method.

\section{HASIL DAN PEMBAHASAN}

Berdasarkan data yang telah terkumpul, dari sampel yang telah memenuhi kriteria purposive sampling (589 data) selama tahun 2011-2017 dapat dilakukan kajian deskiptif sebagai berikut:

Tabel 1. Descriptive Statistics

\begin{tabular}{|c|l|r|r|r|r|r|}
\hline No & \multicolumn{1}{|c|}{ Variabel } & \multicolumn{1}{c|}{ Range } & \multicolumn{1}{c|}{ Min } & \multicolumn{1}{c|}{ Max } & \multicolumn{1}{c|}{ Mean } & \multicolumn{1}{c|}{$\boldsymbol{S D}$} \\
\hline 1 & Profitabilitas (X1) & 71,59 &, 01 & 71,60 & 8,27 & 9,10 \\
2 & Likuiditas (X2) & 962,03 &, 12 & 962,15 & 77,22 & 148,40 \\
3 & Struktur Modal (Y) & 94,06 &, 04 & 94,10 & 1,37 & 4,12 \\
\hline
\end{tabular}

Sumber : data sekunder diolah (2020).

Dari 589 perusahaan selama periode penelitian mempunyai range yang sangat tinggi antara perusahaan yang capaian profitabilitas terendah dengan tertinggi. Range tersebut sebesar $71,59 \%$, artinya bahwa terjadi kesenjangan yang sangat jauh capaian profitabilitas antar perusahaan. Kesenjangan ini nampak dari capaian profitabilitas terendah $0,01 \%$, dan capaian tertinggi $71,60 \%$. Perusahaan yang mempunyai profitabilitas terendah adalah PT. Toba pulp lestari Tbk (INRU) pada tahun 2011, dan PT. Barito Pasific Tbk (BRPT) pada tahun 2015 yang termasuk dalam sektor industri dasar dan kimia. Berikutnya pada tahun 2011 di sektor sektor aneka industri yaitu PT. Nusantara Inti Corpora Tbk (UNIT). Capaian 
profitabilitas tertinggi sebesar $71,60 \%$ oleh PT. Multi Prima Sejahtera Tbk (LPIN) tahun 2011 di sektor sektor aneka industri. Berikutnya diperoleh rata-rata (mean) kemampuan dari 589 perusahaan pada industri manufaktur yang terdaftar di BEI dari tahun 20112017 sebesar 8,27\% dengan standar deviasi 9,10.

Pada industri Manufaktur yang terdaftar di BEI dari tahun 2011-2017 dari 589 perusahaan selama periode penelitian mempunyai range yang sangat tinggi antara perusahaan yang capaian likuiditas terendah dengan tertinggi. Range tersebut sebesar $962,03 \%$, artinya bahwa terjadi kesenjangan yang sangat jauh capaian likuiditas antar perusahaan selama periode penelitian ini. Kesenjangan ini nampak dari capaian likuiditas terendah $0,12 \%$, dan capaian tertinggi $962.15 \%$. Perusahaan yang mempunyai likuiditas terendah adalah PT. Citra Turbindo Tbk (CTBN), dan tertinggi pada PT. DPNS (Duta Pertiwi Nusantara). Kedua perusahaan tersebut terjadi pada tahun 2015 yang termasuk dalam sektor Industri Dasar dan Kimia. Berikutnya diperoleh rata-rata (mean) capaian likuiditas dari 589 perusahaan pada industri Manufaktur yang terdaftar di BEI dari tahun 2011-2017 sebesar $77,22 \%$ dengan standar deviasi 148,40. Hasil rata-rata ini menunjukan bahwa memang pada periode penelitian capaian likuiditas mempunyai rata-rata yang tinggi.

Penelitian ini mempunyai range yang sangat tinggi antara perusahaan yang capaian DER terendah dengan tertinggi. Range tersebut sebesar $94,06 \%$, artinya bahwa terjadi kesenjangan yang sangat jauh capaian DER antar perusahaan-perusahaan yang diteliti selama periode penelitian ini. Kesenjangan ini nampak dari capaian DER terendah $0,04 \%$, dan capaian tertinggi 94,10\%. Perusahaan yang mempunyai DER terendah adalah PT. Kertas Basuki Rachmat Indonesia Tbk (KBRI) tahun 2012 yang termasuk dalam sektor Industri Dasar dan Kimia. DER tertinggi adalah PT. Sumalindo Lestari Jaya Tbk (SULI) tahun 2012 juga termasuk dalam sektor Industri Dasar dan Kimia. Diperoleh rata-rata (mean) capaian DER dari 589 perusahaan pada industri Manufaktur yang terdaftar di BEI dari tahun 20112017 sebesar 1,37\% dengan standar deviasi 4,12. Hasil rata-rata ini menunjukan bahwa capaian DER tertinggi jauh di atas rata-rata seluruh perusahaan, dengan demikian juga mengindikasikan perusahaan tersebut memiliki total hutang jangka panjang yang lebih tinggi.

Selanjutnya dilakukan pengujian terhadap masalah-masalah asumsi klasik, sebagaimana yang nampak sebagai berikut :

Tabel 2. Uji Asumsi Klasik

\begin{tabular}{|l|c|c|c|}
\hline \multicolumn{1}{|c|}{ Uji } & Alat Uji & Hasil & Kesimpulan \\
\hline Normalitas & Z skewness & 1,431 & Normal \\
\hline Heteroskedastisitas & WLS $\left(\mathrm{R}^{2}\right)$ & 0,014 & $\begin{array}{c}\text { Tidak terjadi } \\
\text { heteroskedastisitas }\end{array}$ \\
\hline Autokorelasi & DW & 1,721 & Tidak terjadi autokorelasi \\
\hline $\begin{array}{c}\text { Multikolinieritas : } \\
\text { Profitabilitas }\end{array}$ & VIF & 1,006 & Tidak terjadi \\
Likuiditas & & 1,006 & multikolinieritas \\
\hline
\end{tabular}


Sumber : data sekunder diolah (2020).

Uji normalitas dilakukan dengan 9 (sembilan) langkah uji residual (RES), dengan demikian melalui 7 (tujuh) kali uji outlier. Uji RES-1 dilakukan terhadap 589 data sampel (terjadi outlier data), hingga RES-9 pengujian tinggal 444 data yang tidak terjadi outlier. Berdasarkan langkah ini, sehingga data yang terjadi outlier sebanyak 145 data, sehingga dikeluarkan dari data penelitian ini. Pada RES-9 diperoleh nilai skewness sebesar 0,166 dan nilai standart error of skewness sebesar 0,116 maka diperoleh nilai Zskewness sebesar 1,431. Distribusi data dinyatakan normal jika Zskewness $<2,00$. Hasil ini membuktikan bahwa $1,431<2,00$ sehingga pada persamaan ini distribusi data adalah normal dengan jumlah data 444, yang akan digunakan untuk pengujian selanjutnya.

Uji heteroskedastisitas pertama dengan menggunakan uji Gletser, membuktikan bahwa seluruh variabel independen mempunyai nilai signifikansi < 0,05 (signifikan) sehingga terjadi masalah heteroskedastisitas. Langkah selanjutnya dilakukan dengan melakukan transformasi dengan uji

Tabel 3. Uji Model dan Uji Hipotesis

\begin{tabular}{|c|l|c|c|c|c|}
\hline \multirow{2}{*}{ Uji } & \multicolumn{2}{|c|}{ Variabel } & $\boldsymbol{\beta}$ & Sig. t & Kesimpulan \\
\cline { 2 - 5 } & \multicolumn{1}{|c|}{ Independen } & Dependen & & & \\
\hline H1 & Profitabilitas & Struktur & $-0,363$ & 0,000 & H1 terbukti \\
H2 & Likuiditas & modal & $-0,230$ & 0,000 & H2 terbukti \\
\hline \multicolumn{3}{|l|}{} & Sig. F & 0,000 & \\
& Adjusted $R^{2}$ & & 0,194 & \\
\cline { 1 - 4 }
\end{tabular}

Sumber : data sekunder diolah (2019).

Persamaan jalur diperoleh nilai signifikansi $F$ sebesar 0,000 dengan demikian dapat disimpulkan bahwa variabel profitabilitas dan likuiditas mampu menjelaskan variabel struktur modal secara signifikan pada tingkat alpha 5\%. Nilai adjusted $R$ square
Weighted Least Square (WLS). Hasil pengujian membuktikan bahwa chi square hitung < chi square tabel $(0,014<5,99)$, sehingga dengan transformasi WLS tidak terjadi heteroskedastisitas.

Uji autokorelasi dengan menggunakan uji Durbin Watson (DW) diperoleh nilai Dw sebesar 1,721; nilai Du sebesar 1,848; dan nilai 4-Du sebesar 2,152. Hasil ini membuktikan bahwa $\mathrm{Du}<\mathrm{Dw}<4$-Du $(1,848<1,721$ $<$ 2,152), dengan demikian dapat disimpulkan bahwa tidak terjadi masalah autokorelasi.

Uji multikolinieritas dengan menggunakan uji Variance Inflation Factor (VIF). Model dalam persamaan dinyatakan tidak terjadi multikolinieritas apabila nilai VIF $<10$. Berdasarkan hasil pengolahan data seluruh variabel independen mempunyai VIF < 10. Variabel profitabilitas dan likuiditas masingmasing memperoleh VIF sebesar 1,006. Hasil pengujian ini dapat disimpulkan bahwa seluruh variabel independen tidak terjadi masalah multikolinieritas.

Selanjutnya uji model dan uji hipotesis dilakukan sebagai berikut : sebesar 0,194 artinya bahwa variabel profitabilitas, dan likuiditas mampu menjelaskan variabel struktur modal sebesar 19,4\%. Selebihnya, 80,6\% variabel struktur modal dijelaskan oleh variabel lain yang tidak termasuk dalam model penelitian ini, misalnya terkait faktor teknikal. 
Tabel 3 menunjukan hasil uji hipotesis membuktikan sebagai berikut : 1. Pengaruh Profitabilitas Terhadap Struktur Modal (H1)

Pecking order theory atau disebut pula teori urutan pendanaan mendasarkan pada pemahaman bahwa perusahaan melakukan pembiayaan investasi dari berbagai sumber (interrnal maupun eksternal). Teori ini menurut Manurung (2012:24) juga membahas mengenai sumber pembiayaan atau pendanaan. Urutan sumber pendanaan tersebut dimulai dari penggunaan laba ditahan, mencairkan surat berharga (deposito, menjual obligasi dan saham), menerbitkan surat hutang, dan menerbitkan saham.

Teori ini pertama kali diperkenalkan oleh Gordon Donaldson pada tahun 1961 dalam penelitiannya terhadap 500 perusahaan. Hasil penelitian menunjukkan 176 perusahaan dan menganalisis praktek pembiayaan perusahaan dari 25 perusahaan dengan hasil bahwa perusahaan mempunyai urutan dalam melakukan pembiayaan dimulai dengan urutan laba ditahan, hutang kepada pihak ke tiga baik dengan loan atau jual obligasi dan terakhir dengan mengeluarkan saham baru. Urutan pendanaan tersebut merupakan urutan berdasarkan biaya yang harus dikeluarkan perusahaan dan biaya ekuitas merupakan biaya tertinggi (Manurung, 2012:24).

Menurut hipotesis pecking order sebagaimana yang dinyatakan dalam penelitian Seifert et al (2010) bahwa, pembiayaan yang dihasilkan secara internal lebih dijadikan pilihan utama bagi perusahaan. Kebutuhan dana berikutnya diikuti oleh hutang yang paling aman dan kemudian yang berisiko, kemudian keputusan pendanaan yang terakhir dari eksternal.

Seifert et al (2010) lebih lanjut menyatakan, apabila perusahaan tidak memerlukan banyak pembiayaan dari eksternal, maka kemungkinan dapat memenuhi kebutuhannya dengan sumber-sumber internal, misalnya melalui laba. Struktur modal perusahaan mencerminkan pada sebagian besar kebutuhan akan dana (investasi dan dividen) dan berapa banyak dari kebutuhan tersebut dipenuhi oleh pendapatannya.

Baskin (1989) dalam Manurung (2012:25), pada penelitiannya pengaruh antara profitabilitas dan pertumbuhan perusahaan dengan tingkat leverage. Peningkatan profitabilitas di masa lalu akan mengurangi leverage perusahaan di masa sekarang. Profitabilitas perusahaan yang meningkat, maka leverage perusahaan akan mengalami penurunan. Hasil penelitian juga mengungkapkan bahwa, kenaikan pertumbuhan perusahaan, maka berdampak pada meningkatnya leverage.

Hasil penelitian ini mendukung pecking order theory, pembuktikan secara statistik nampak bahwa nilai koefisien regresi $(\beta 1)$ sebesar $-0,363$ dengan signifikansi 0,000. Dengan demikian hipotesis (H1) yang menyatakan bahwa profitabilitas berpengaruh negatip terhadap struktur modal terbukti. Selain itu juga dalam penelitian ini, mempunyai pengaruh yang lebih besar dibandingkan dengan variabel lainnya terhadap struktur modal. Profitabilitas yang tinggi berarti perusahaan mempunyai dana internal yang cukup untuk membiayai operasional perusahaan. Dampaknya maka bagi para manajer dalam pembiayaannya lebih memilih mengurangi leverage, hal ini bukan karena perusahaan tidak membutuhkan dana eksternal, namun dikarenakan pertimbangan bahwa menggunakan dana internal sudah cukup.

Strategi ini tentunya menjadi salah satu pertimbangan bahwa perusahaan- 
perusahaan industri Manufaktur yang tercatat di Bursa Efek Indonesia dalam menghindari atau mengurangi risiko. Industri manufaktur mempunyai nilai investasi dan modal kerja yang sangat tinggi, sehingga tingkat risiko yang tinggi pula. Profitabilitas yang tinggi berarti perusahaan mempunya kinerja keuangan yang sangat baik, dengan demikian para manajer akan melakukan pengelolaan dana internal yang maksimal. Tingginya hutang dapat berdampak pada kebangkrutan, apabila perbandingan antara manfaat yang diterima tidak lebih besar dari biaya yang harus ditanggung oleh perusahaan. Salah satu biaya yang dimaksud adalah biaya bunga, dan pada waktunya harus membayar bunga dan pokok, bahkan apabila terjadi keterlambatan mempunyai konsekuensi denda. Kebangkrutan yang disebabkan oleh faktor keuangan, merupakan systematic risk dengan demikian dapat dihindari melalui manajemen yang baik.

Studi empiris yang dilakukan oleh Purwohandoko (2017), Guner (2016), Serghiescu, dan Viorela Ligia Videan (2014), Handoo, dan Kapil Sharma (2014), dan Ghatak (2012) mendukung hasil penelitian ini. Kajian dari studi empiris dari penelitian terdahulu tersebut, menyimpulkan bahwa profitabilitas berpengaruh negatip dan signifikan terhadap struktur modal.

2. Pengaruh Likuiditas Terhadap Struktur Modal (H2)

Mayers (1984) dalam Seifert et al (2010) melakukan modifikasi terhadap hipotesis pecking order. Dinyatakan apabila perusahaan mempunyai peluang yang banyak atas investasi di masa depan, maka dapat memutuskan untuk mengeluarkan ekuitas dalam pendanaannya. Tujuan mengeluarkan ekuitas ini tentunya untuk membangun kelonggaran atau kelebihan keuangan, sehingga dapat melakukan peluang investasi masa depan yang lebih luas.

Berdasarkan perspektif investor luar, pemilihan ekuitas lebih berisiko dari pada hutang. Keduanya memiliki risiko, namun premi lebih besar pada ekuitas. Berdasarkan pertimbangan tersebut, maka investor luar akan menuntut tingkat pengembalian ekuitas yang lebih tinggi dari pada hutang. Dilihat dari perspektif investor di dalam perusahaan, laba ditahan adalah sumber dana yang lebih baik daripada utang, dan utang adalah kesepakatan yang lebih baik dari pada pembiayaan melalui ekuitas. Berdasarkan hal tersebut dan jika memungkinkan, maka perusahaan akan mendanai semua proyek dengan menggunakan laba ditahan. Pembiayaan dari laba ditahan tidak memadai, maka perusahaan akan melakukan pembiayaan dari hutang. Pada kondisi perusahaan yang normal, maka ekuitas tidak akan digunakan (Frank et al, 2003).

Perspektif positip dari hipotesis pecking order adalah bahwa manajer memiliki informasi lebih banyak tentang nilai perusahaan, dibandingkan dari para investor luar. Hal ini akan dapat menimbulkan asimetri informasi. Permasalahan ini membuat para manajer waspada terhadap penerbitan ekuitas, karena tindakan ini akan berdampak pada persepsi investor. Para investor akan menafsirkan tindakan peneribitan ekuitas sebagai berita buruk. Investor akan berasumsi bahwa manajer mengeluarkan saham (ekuitas) dikarenakan harga saham perusahaan dinilai terlalu tinggi (Seifert et al, 2010).

Seifert et al (2010) yang melakukan pengujian terhdap peranan hipotesis pecking order terhadap perusahaan-perusahaan besar. Pengujian dilakukan menggunakan sampel perusahaan dari 4 (empat) negara yaitu Amerika Serikat, Inggris, Jerman, dan Jepang. Beberapa penelitian sebelumnya 
menunjukan bahwa hipotesis pecking order berlaku untuk perusahaan besar atau perusahaan mapan. Hasil empiris dari Seifert et al (2010) menemukan hanya sedikit dukungan terhadap hipotesis pecking order untuk perusahaan-perusahaan di Amerika Serikat, Inggris, dan Jerman. Bukti lain memberikan dukungan yang lebih besar bagi perusahaan di Jepang.

Pengujian terhadap hipotesis/teori pecking order juga dilakukan oleh Besller et al (2010). Penelitian menggunakan sampel secara internasional dengan lebih dari 6.000 perusahaan. Hasil penelitian membuktikan adanya gap terhadap prediksi teori pecking order. Terdapat korelasi yang tinggi antara defisit pembiayaan dengan masalah ekuitas. Pada regresi time series menunjukan bahwa dengan perubahan dalam hutang bersih (variabel dependen), dan defisit financing (variabel penjelas), bahwa teori pecking order terbukti untuk perusahaan non-Amerika Serikat. Disimpulkan pula bahwa bahwa pendanaan sebagian besar mendiskreditkan prediksi teori pecking order. Asumsinya bahwa terdapat asimetri informasi merupakan penentu yang sangat penting dalam pengambilan keputusan struktur modal. Perusahaan mengeluarkan jumlah ekuitas yang lebih besar ketika asimetri informasi rendah.

Pengujian hipotesis mengenai pengaruh likuiditas terhadap struktur modal $(\mathrm{H} 2)$, juga mendukung pecking order theory tersebut. Pembuktikan secara statistik nampak bahwa nilai koefisien regresi ( $\beta 2)$ sebesar $-0,230$ dengan signifikansi 0,000 . Hipotesis (H2) yang menyatakan bahwa likuiditas berpengaruh negatip terhadap struktur modal dapat diterima. Likuiditas yang tinggi diartikan oleh para kreditur bahwa perusahaan tidak mampu memutar dananya, sehingga banyak dana yang menganggur. Risiko yang dapat muncul pada perusahaan dalam kondisi seperti ini dari waktu ke waktu kinerja keuangan menurun.

Pada perusahaan-perusahaan industri Manufaktur khususnya yang tercatat di Bursa Efek Indonesia merupakan skala perusahaan besar, dengan demikian dibutuhkan nilai modal kerja yang tinggi pula. Kondisi ini menuntut para manajer untuk mampu mengelola modalnya dengan efektif. Salah satunya dengan mengambil strategi adanya keseimbangan dilikuiditas, karena akan berdampak pada aliran kas. Tingginya likuiditas bisa disebabkan diantaranya posisi kas masuk yang tinggi, modal terlalu banyak tertahan di persediaan, dan bahkan piutang.

Kas yang tinggi pada perusahaan menunjukan adanya dana yang tidak produktif, dampaknya bisa menurunkan keuntungan. Tingginya persediaan, maka dana akan tertahan di bahan baku, barang setengah jadi, dan bahkan barang jadi. Hal ini mengindikasikan dengan bahan baku yang tinggi berarti perusahaan tidak melakukan proses produksi yang diakibatkan oleh permintaan yang tidak bertambah bahkan menurun, tentunya hal ini menunjukan bahwa kinerja marketing yang rendah. Faktor lain yaitu dimungkinkan karena piutang yang tidka tertagih tinggi, sehingga modal kerja tidak cepat berputar. Permasalahanpermasalahan tersebut menjadikan penilaian negatip dari kreditur, dampaknya tidak menaruh kepercayaan lagi pada perusahaan yang dalam kondisi seperti ini, akibat selanjutnya struktur modal berkurang.

Studi empiris yang dilakukan oleh Guner (2016), Alfi dan MH. Safarzadeh (2016), Ghasemi dan Nazrul Hisyam Ab Razak (2016), Serghiescu, dan Viorela Ligia Videan (2014), Kausar et al 
(2014), Indriani dan Endang Tri Widyarti (2013), mendukung hasil pengujian dalam penelitian ini. Kajian dari studi empiris dari penelitian terdahulu tersebut, menyimpulkan bahwa likuiditas berpengaruh negatip dan signifikan terhadap struktur modal.

\section{SIMPULAN DAN SARAN}

Simpulan dari hasil penelitian ini bahwa secara parsial, profitabilitas dan likuiditas berpengaruh negatip dan signifikan terhadap struktur modal. Bagi para akademisi, hasil penelitian ini dapat dijadikan acuan sebagai pengembangan pengujian terhadap pecking order theory. Bagi para pihak yang ada di jajaran manajerial perusahaan, maka pengujian ini menjadi rambu-rambu dalam pengambilan keputusan dalam menyusun struktur modalnya. Mengacu kesimpulan di atas, bahwa teori pecking order terbukti secara signifikan, maka sebaiknya ketika profitabilitas dan likuiditas perusahaan tinggi, para manajer tidak mengambil keputusan pendanaan dari eksternal, dengan demikian perusahaan menggunakan dana internal semaksimal mungkin, karena dapat mengurangi risiko. Calon investor dan investor sebaiknya melakukan investasi pada perusahaan yang mempunyai profitabilitas dan likuiditas tinggi, karena memiliki tingkat leverage yang rendah.

\section{DAFTAR PUSTAKA}

Alfi, Shohreh, dan Mohammad Hossein Safarzadeh et al, 2016, Effect of Capital Structure Andliquidity On Firm Value, IJABER, Vol. 14, No. 14 (2016): 10143-10153.

Frank, Murray Z. dan Vidhan K. Goyal et al, 2003, Testing the pecking order theory of capital structure, Journal of Financial Economics 67 (2003) 217-248.

Ghasemi, Maziar, dan Nazrul Hisyam Ab Razak et al, 2016, The Impact of Liquidity on the Capital Structure: Evidence From Malaysia, International Journal of Economics and
Finance; Vol. 8, No. 10; 2016 ISSN 1916-971X E-ISSN 1916-9728, Published by Canadian Center of Science and Education.

Ghatak, Anirban et al, 2012, Testing of Pecking Order Theory in the context of SMEs in India, Volume: 02, Number: 01.

Handoko, Didy, 2016, The Influence Of Firm Characteristics On Capital Structure And Firm Value: An Empirical Study of Indonesia Insurance Companies, International Journal of Economics, Commerce and Management, Vol. IV, Issue 4, April 2016, ISSN 23480386.

Indriani, Astiwi, dkk, 2013, Penentu-Penentu Struktur Modal Perusahaan Yang Sahamnya Masuk Jakarta Islamic Index, JDM Vol. 4, No. 1.

Kausar, Asifa dan Mian Sajid Nazir, Hashim Awais Butt et al, 2014, Capital Structure and Firm Value: Empirical Evidence from Pakistan, Volume 1 - Issue 1, March - April, 2014 [11-22].

Manurung, Adler Haymans, 2012, Konsep dan Empiris Teori Investasi, PT. Adler Manurung Press, Jakarta.

Manurung, Adler Haymans, 2012, Teori Keuangan Perusahaan, PT. Adler Manurung Press, Jakarta.

Putu, Ni Nyoman G Martini, Moeljadi, Djumahir, Atim Djazuli et al, 2014, Factors Affecting Firms Value of Indonesia Public Manufacturing Firms, International Journal of Business and Management Invention ISSN (Online): 2319 8028, ISSN (Print): $2319-801 X$ www.ijbmi.org Volume 3 Issue 2\| February. 2014\| PP.35-44.

Purwohandoko, 2017, The Influence of Firm's Size, Growth, and Profitability on Firm Value with Capital Structure as the Mediator: A Study on the Agricultural Firms Listed in the Indonesian Stock Exchange, International Journal of Economics and Finance; Vol. 9, No. 8; 2017, ISSN 1916-971X E-ISSN 1916-9728.

Salvatore, Dominick. 2005. Ekonomi Manajerial dalam Perekonomian Global. Jakarta. Salemba Empat.

Seifert, Bruce et al., 2010, The International Evidence on The Pecking Order Hypotesis, University of Groningen.

Purwohandoko, 2017, The Influence of Firm's Size, Growth, and Profitability on Firm Value with Capital Structure as the Mediator: A Study on the Agricultural Firms Listed in the Indonesian Stock Exchange, International Journal of Economics and Finance; Vol. 9, No. 8; 2017, ISSN 1916-971X E-ISSN 1916-9728.

ttp://warungkopi.okezone.com/thread/654956/perkemb angan-investasi-di-indonesia-tahun-2017, Upload 19 September 2017, Download 20 November 2017.

http://etd.repositorv.ugm.ac.id/index.php?mod=penelit $\underline{\text { ian detail \&sub }=\text { penelitiandetail\& } a c t=v i e w \& t y p}$ $=h \mathrm{tml} \&$ buku $i d=77819$, upload 19 september 2017, download 20 november 2017, ibrahim, nofansyah, electronic thesis and dissertation, gadjah mada univercity.

https://www.kemenkeu.go.id/sites/default/files/kajian\% 20dampak\%20asean.pdf, Laporan Dampak Asean Economic Community Terhadap Sektor 
Jurnal Bingkai Ekonomi Vol. 5, No. 2 , 2020, pp: 27 - 36

Industri Dan Jasa, Serta Tenaga Kerja Di Indonesia, Nomor LAP-10/KF.4/2014, Jakarta,
Desember 2014. 